\title{
From Rowdy Cartels to Organized Ones? The Transfer of Power in Urban Water Supply in Kenya
}

\author{
Akosua Sarpong Boakye-Ansah, et al. [full author details at the end of the \\ article]
}

Published online: 12 April 2019

(C) The Author(s) 2019

\begin{abstract}
Due to the limited presence of formal water utilities in urban low-income areas in many developing countries, water supply is carried out by informal private providers. As part of efforts towards improving water services to low-income areas, the activities of these informal providers are currently being acknowledged through various formalization approaches. This article investigates one such formalization approach, which consists of partnerships between the utility and the informal providers. This is an approach which allows the utility to partially withdraw from service provisioning to the low-income areas. Based on empirical evidence from three such partnerships in low-income areas in three Kenyan cities, we show in this article that formalization redefines and strengthens the legal capacity of informal providers to gain control of service provision in these areas. This can bring benefits for the utility as well as for consumers. However, it also risks legitimizing and furthering the exploitation of consumers by informal providers.
\end{abstract}

Keywords Formalization · Partnerships $\cdot$ Informal water providers $\cdot$ Formal water utility $\cdot$ Low-income areas $\cdot$ Kenya

\section{Résumé}

En raison de la présence limitée de services d'eau officiels dans les zones urbaines à faible revenu de plusieurs pays en développement, l'approvisionnement d’eau est assuré par des prestataires privés informels. Pour améliorer les services d'eau dans les zones à faible revenu, les activités de ces fournisseurs informels sont actuellement reconnues par diverses approches de formalisation. Cet article examine une de ces approches de formalisation, en l'occurrence, celle qui se compose de partenariats entre le service public et les fournisseurs informels. C'est une approche qui permet au service public de se retirer partiellement de la fourniture de services d'eau dans les zones à faible revenu. Á partir des preuves empiriques issues de trois partenariats de ce type dans trois villes du Kenya, nous montrons dans cet article que la formalisation redéfinit et renforce la capacité juridique des fournisseurs informels à maîtriser la fourniture de services dans ces domaines. Cela peut présenter des avantages tant pour le service public que pour les consommateurs. Cependant, cela risque aussi 
de légitimer et de favoriser l'exploitation des consommateurs par des fournisseurs informels.

\section{Introduction}

The different policies, programmes and projects devised over the past decades to improve access to water and sanitation in African cities have done little to expand services to large segments of the rapidly increasing urban population. The reforms of the 1990s, which were geared towards commercialization, public private partnerships and the opening up of the sector for the introduction of different forms of competition (Jaglin 2016, p. 186; see also Cosgrove and Rijsberman 2000; Winpenny 2003; World Bank 2003), did not produce the expected extension of the water network, at least not to all areas within cities. Urban water supply in most African cities remains characterized by low coverage and erratic supply, with the wealthier inhabitants enjoying better services than those residing in low-income areas (Water and Sanitation Program-WSP 2005). Illustrative of this situation is the Kenyan water sector, where 98 registered water utilities only serve about $55 \%$ of the population (Water Services Regulatory Board-WASREB 2016).

Most water utilities associate low-income areas (LIAs) with widespread illegal water connections, low payment of bills and a high frequency of service disconnection (Heymans et al. 2014, p. 3). This results in high quantities of so-called non-revenue water (NRW): water that is not formally accounted or paid for. NRW, roughly the difference between water delivered and water billed and paid for, is one of the most important performance indicators for water providers-as it is an indication of the financial sustainability of the service provider (Castro and Morel 2008; Schwartz et al. 2017). The difficulty in properly accounting for and billing the water delivered to low-income areas is the main reason that most water utilities consider service delivery to these areas a burden (Heymans et al. 2014; Berg and Mugisha 2010). Subsequently, they prefer to expand services to those areas where tariff collection is easier, and immediate financial returns are more promising (Castro and Morel 2008, p. 291).

The resulting gap in formal water supply in African urban low-income areas is often filled by informal modes of water supply (see also Burt and Ray 2014; Harris and Janssens 2004; Jaglin 2008, 2014; Bakker 2003; Sima and Elimelech 2011). Where water supply is unreliable or in areas that have rapidly developed and are not (yet) connected to the formal network, informal suppliers thrive (Sima and Elimelech 2011; see also Angueletou-Marteau 2008; Batley 2006; Kariuki and Schwartz 2005; Misra 2014). Many of the informal providers engage in water provisioning in LIAs because they consider it an interesting business opportunity. Since their earnings depend on the failure of formal utilities to provide reliable access, they have an incentive to artificially create shortages, by vandalising water pipes or cutting off the water supply to residents (Water Services Trust Fund-WSTF 2010). In Kenya, water provided by informal providers is sometimes sold at prices 10 times higher than the official prices to which the formal providers must adhere. Water can be sold for as high as 20 Kenyan shillings (Ksh) (0.19 USD) instead of the recommended 


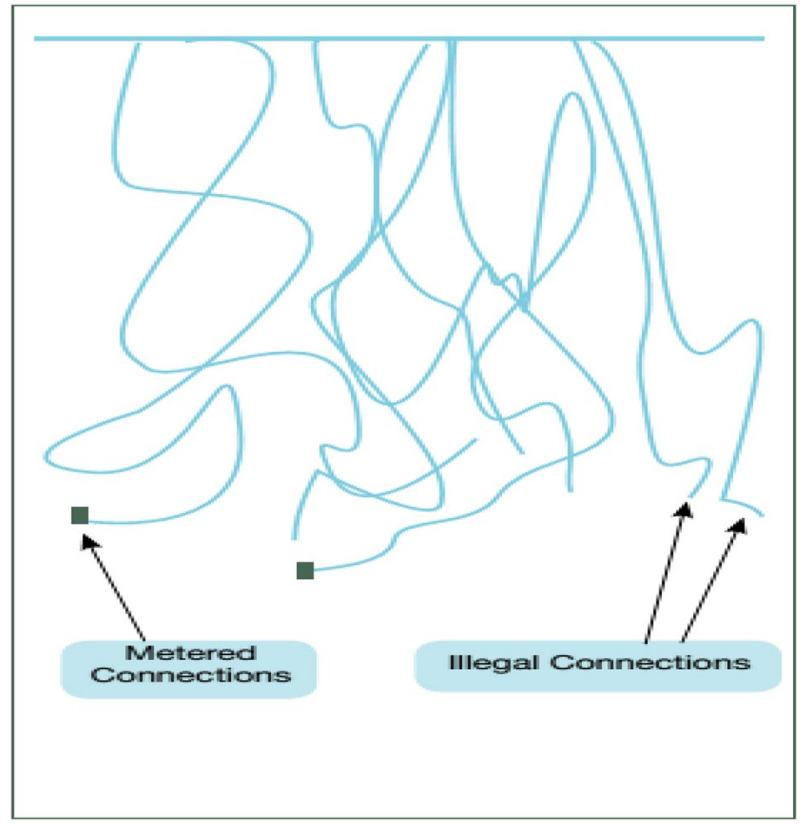

Fig. 1 Schematic presentation of messy 'spaghetti network' system, source (WSP 2009)

2 Ksh (0.02 USD) for a 20-1 gallon, even when the water is of questionable quality. Informal providers may also obtain their water by illegally connecting to the water network of formal water utilities (WSTF, 2010). They tend not to follow laid down patterns for their distribution networks, resulting in the messy piped network systems sometimes referred to as 'spaghetti networks' (Fig. 1). It often happens that these pipes are connected through sewers or laid out on streets and pathways, making them susceptible to frequent breaks and leaks. With the poor sanitary conditions in these areas, the water transported through these pipes also becomes easily contaminated.

In Kenya, the rowdy and exploitative nature of the activities of the informal water operators has earned them the name 'Water Cartels'. Members of these cartels not only include the owners of water points but also the owners of the carts used to transport water to households, cart pushers, and legal or illegal landlords or landowners. In low-income areas where the formal water utility did manage to develop water provision services, these often ended up being controlled by cartel members. An estimated 55 of such cartels were operating within three LIAs (Obunga, Manyatta and Nyalenda) in Kisumu. ${ }^{1}$ As residents have few or no alternatives, other than not having access to water or collecting it from contaminated sources, ${ }^{2}$ they remain dependent on the informal water providers. Subsequently, there have been calls to

\footnotetext{
1 Interview, Staff, KIWASCO, 14 March 2018.

2 Interview, Staff GIZ, Nairobi, 4 April 2017.
} 
formalize and recognize their activities (De Soto 2000; Harris and Janssens 2004; Njiru 2004; Schaub-Jones 2008; Solo 1999; World Bank 2009). In formulating this call, proponents argue that the recognition will limit the regulatory and financial constraints the informal providers encounter in the course of carrying out their activities (Conan 2003; Conan and Paniagua 2003). The ultimate winner of formalization will then be the consumer, who will enjoy better and cheaper service options. In this article, through case studies from low-income areas in three Kenyan cities, where the formal water utilities are partnering with small-scale providers to deliver water to residents, we aim to assess the development of such partnerships in the water sector. We develop our assessment by first presenting the different approaches adopted towards formalization of informal providers in the water sector. We show that, whereas initially the concept of formalization was opposed by formal water utilities, formalization through the development of partnerships to serve LIAs has become an acceptable approach for the water utilities. The article further presents the case studies and ends by discussing the concerns that emanate from these case studies regarding the outcomes of formalization on consumers in low-income areas. Our discussion finds that although the partnership approach to formalization can bring benefits, it also raises strong concerns about the possible exploitation of consumers by formalized small-scale providers operating in partnership with the water utility. Their newly obtained legal status and space does not just make it possible to better control and regulate their behaviours and services, but also allow these providers to wield more influence and power and thus increase opportunities for abuse. This, in turn, can lead to exacerbating the very inequalities that formalization seeks to eliminate.

\section{Approaches Towards Formalization of Informal Providers}

Informal providers do not normally conform to the existing rules and regulations that guide formal water delivery in cities, which is why their activities are considered illegal. By such classification, the informal means of water delivery is considered residual or provisional and temporary. With time, they are expected to be gradually replaced by more formal modes of service provisioning (Jaglin 2016). Unlike their formal counterparts, the illegality of informal providers also means that they are not eligible for financial support from government agencies, donors or banks. By calling them illegal, informal providers were simply not expected to improve and expand their services, as this would make them more permanent.

Instead of expecting informal providers to gradually disappear, an approach that gained popularity since the 1990s is to consider their activities as creative and entrepreneurial, and their services as potentially durable. This legalistic approach to formalization argues that, by acknowledging the existence of informal providers and regularising their activities, they become part of the formal market systems (Ahlers et al. 2013; Moretto 2007; Schaub-Jones 2008). The approach acknowledges that the informal status of such providers forms a constraint to their longer-term success, while also hindering the improvement of water services provision in areas that formal utilities do not reach. Rather than allowing illegality to thrive (De Soto 2000), 
this approach promotes the formalization of informal providers as a way of bringing these small-scale providers into the formal water services system. This approach gained particular prominence in policy literature stemming from the International Development Banks (Solo 1999; World Bank 2009).

Formalization through this approach emphasizes that providing legal titles and imposing light-handed regulation to control quality and prices makes it possible for informal providers to have access to adequate financial support (in forms of loans and credits at commercial rates), which allows them to legally invest in their enterprises and access water sources. This in turn is expected to provide them with the incentive needed to reduce the cost of water sold to consumers, as well as to put a halt to their illegal practices in terms of connecting to water sources or networks of formal water utilities. In the longer term, formalization is expected to help unleash a healthy entrepreneurialism in the water sector, by helping markets to emerge in which providers have to compete for customers (Ahlers et al. 2013, p. 470). This competition is expected to lead to lower prices and also allow consumers to have choices regarding the level of service that they prefer (Johnstone et al. 1999; Njiru 2004; Solo 1999; World Bank 2009).

In sum, the legalistic approach to formalization marks a shift from the government sanctioned monopoly in which formal water utilities are the sole providers of water services (characteristic of the so-called Modern Infrastructural Ideal) to a market of multiple private suppliers who compete with each other. Lowering the barriers for small-scale providers to formally enter the water services market by creating an enabling environment is the cornerstone of this approach. Formalization thus becomes the route for hitherto 'informal' private providers to become sanctioned as legitimate small-scale entrepreneurs in the sector.

Despite considerable interest and promotion by actors such as the World Bank and internationally operating sector consultants, this approach to formalization never really took off. Formal water sector organizations were reluctant to support it as they saw informal providers as undesirable competitors, with competition moreover happening on unfair terms. Other sector organizations, such as water sector regulators, considered it impossible to regulate such a large number of small-scale providers and highlighted that they had little authority in low-income areas (Ahlers et al. 2013).

In recent years, however, the stance of the producer actors, such as water utilities and regulators, towards the idea of formalizing informal providers has changed. Rather than oppose formalization, they increasingly embrace a new form of formalization. This formalization is not based on granting titles to the informal providers and allowing them to operate in the market, but rather consists of incorporating them into the formal service delivery system through partnership arrangements (Moretto 2007). These partnership arrangements position the formal water utility as the bulk supplier of water to small-scale providers, who in turn distribute the bulk water obtained from the water utilities to the endconsumers. An important element of these arrangements is that it does not introduce competition between the water utility and small-scale providers. Rather, small-scale providers will have to compete with each other for a share of the 
low-income markets that the water utility is not able or willing to service (Ahlers et al. 2013; Ranganathan 2014).

\section{Methodology}

This study forms part of a larger study currently being carried out in Kenya that seeks to investigate how water utilities address the challenge of ensuring equitable services within polarized cities. Data were collected from 12 LIAs in Nakuru (Kaptembwo, Rhonda and Githima), Kisumu (Nyalenda, Obunga, Otonglo, Nyamasaria, Ogango and Koyango) and Kericho (Matobo, Nyagacho and Mjini). Data were collected through semi-structured interviews with open-ended questions from residents (30), landlords (13), kiosk operators (10) and small/scale providers (8) from these areas. Furthermore, 60 key respondents, including staff of water utilities, staff of local and international non-governmental organisations (NGOs), bilateral and multilateral agencies and government officials operating in the water sector, and staff of governmental bodies were interviewed. In addition, field observations and the review of documents relevant to the study were carried out. Fieldwork was carried out in January to February 2016, January to April 2017 and January to April, 2018. Respondents provided verbal consent to participate in the study, after the purpose and objectives of the study had been explained to them.

\section{Drivers for the Producer Perspective on Formalization}

In 2002, the Kenyan water sector introduced a series of reforms consisting of an upgraded framework for devolution. The reforms addressed two seemingly contradictory objectives. The first objective was to develop the water utilities in Kenya (so-called Water Service Providers, WSPs) into commercially viable organizations. Prior to the 2002 reforms, water supply was under the direct jurisdiction of the provincial authorities and municipalities. Under this arrangement, water supply in cities, especially in low-income areas, was characterized by non-payment of bills and high levels of non-revenue water. For political expediency, authorities did little to rectify this situation. The 2002 Kenyan Water Act, however, was very much inspired by the concept of commercial public water utilities. WSPs were to operate on the basis of cost-recovery and be financially and managerially ring-fenced in order to avoid political interference in their operations and management. A second objective of the Water Act was to reinforce the Kenyan Constitutional declaration that every Kenyan has the right "to clean and safe water in adequate quantities" (Government of Kenya 2010, p. 31). The focus on access to water services was further supported by the Kenya Vision 2030 and the commitment to Goal 6 of the Sustainable Development Goals, both of which envisage universal access to water by 2030. The WSPs formed the main tool to achieve this aim.

As these two objectives are not always automatically compatible, water utilities started making a sharp distinction between two customer segments. The need to operate on a commercial basis and recover costs pushes WSPs towards high-income 
consumers. These consumers are seen as reliable clients who can easily afford tariffs approaching cost-recovery. ${ }^{3}$ The need to strive for universal service coverage, on the other hand, forces the utility to direct some of its attention to the large section of the urban population residing in LIAs. These are the very consumers to whom the utilities were reluctant to provide services, because they are considered difficult or recalcitrant. ${ }^{4}$ Faced with the dilemma of implementing this 'mixed mandate' (Furlong 2014) of achieving both commercial as well as social objectives, utilities increasingly saw it as appealing to delegate the responsibility (and the risk) of delivering water to low-income areas to small-scale providers through a partnership approach.

Unlike the legalistic approach where the informal operators are equipped to compete with each other in the water sector, this partnership approach allows the formal utility to maintain a monopoly over water services while delegating part of the less-profitable and more risky activities to small-scale providers. This means that the utility conveniently devolves the actual distribution of water as well as the direct interactions with the consumers of low-income areas to small-scale providers. While thus withdrawing from actual service provision to low-income areas, this approach allows WSPs to take credit for addressing the issue of universal access to services, as they maintain the ability to regulate and control supply through their bulk water provision to the small-scale providers. Moreover, consumers in low-income areas may have specific water demands and willingness to pay for services (Njiru et al. 2001). Partnering with small-scale providers, who are often commended for being flexible, could improve the ability of the utilities to respond to the needs of consumers with appropriate service levels (see Boakye-Ansah et al., forthcoming). The producer approach to formalization through partnerships thus presents the opportunity for utilities to get round the challenges of servicing the low-income areas and balance their financial with their social mandates.

The partnership approach also has an additional benefit in that it 'normalizes' the relationship between the water utility and the Water Cartels, who were previously involved in creating artificial shortages through the vandalism of utility pipes and controlling the local water market. Prior to the formation of these partnerships, WSPs tried different approaches to remove the cartels, for instance by disconnecting illegal networks. This was driven by the fact that the high NRW rates recorded by the water utilities were, at least partially, attributed to the activities of the cartels. The hope was that, after the illegal connections have been taken out of the system, cartel-operated small-sale providers would approach the utilities for them to be connected legally. However, the high connection fee and the desire to continue making money out of the informal provisioning ${ }^{5}$ dissuaded both residents and cartels from approaching the utilities for connections. Residents were therefore left without access to clean water-making them vulnerable to water-borne diseases. Formalizing these providers through partnerships instead allows these cartels to be integrated into the formal delivery system. In other words, by partnering with the small-scale

\footnotetext{
3 Interview, lecturer University of Nairobi, 9 February 2017.

${ }^{4}$ Interview, lecturer University of Nairobi, 9 February 2017.

5 Interview, staff GIZ, Nairobi, 4 April 2017.
} 
providers, the utility seeks to work together with established cartel members who will otherwise 'frustrate' their efforts of supplying water to low-income areas. ${ }^{6}$ By embracing formalization through partnerships, the producer actors recognise urban heterogeneity and diversity in demand for water and accept that a singular model to water supply cannot satisfy these demands.

\section{Formalizing Informal Providers Through Partnership}

Together with their development partners, WSPs in Kenyan cities introduced the partnership approach to absorb the cartels, involve the community members in the management of their water supply and also further their commercial interests. ${ }^{7}$ The hope and expectation is that these partnerships will help control these rowdy cartels, as well as put an end to the unruly behavior of residents. The latter is expected to happen by allowing them to develop a sense of ownership, so that they assume responsibilities of protecting and maintaining the infrastructure. To summarize these expected outcomes of the approach, an official from a local NGO described it as:

a bottom-up approach which ensures participation by low-income consumers in water-provisioning issues... it has created room for partnerships between the community and the utility and promotes a sense of ownership among consumers; leading to the reduction of vandalism of infrastructure and the removal of cartels who hitherto were exploiting consumers, thereby making water affordable. ${ }^{8}$

In the sections that follow, we describe three mechanisms that WSPs use to partner with the informal providers in serving the urban poor in three Kenyan cities.

\section{From Cartels to Kiosk Operators}

One technology adopted by WSPs to extend supply to the densely populated and often unplanned LIAs is the water kiosk. This technology which was in use in all three cases, typically consists of a device with one or more taps from which a number of people obtain water. It requires an attendant for its operations. These kiosk attendants provide a good entry-point for the WSPs to form partnerships with existing informal providers. Such partnerships are of two types. Under the first arrangement, the WSP takes care of all the investments required for the construction of the kiosk and then hands it over to an attendant. Typically, attendants are drawn from (1) the informal operators (the cartels) who have prior knowledge of water supply in these areas, and (2) the landlords on whose lands the kiosks are constructed. In the second arrangement, WSPs give permission to individuals or groups to construct

\footnotetext{
${ }^{6}$ See also Rusca et al. (2015) for an analysis on the institutionalizing corruption in the formal delivery system in Lilongwe, Malawi, through Water User Associations.

7 Interview, Staff NAWASCO, Nakuru 16 February, 2017.

${ }^{8}$ Interview, NGO staff, Kisumu, 13 March, 2017.
} 
kiosks with their own resources. ${ }^{9}$ Many private providers whose activities were hitherto classified as informal seized this opportunity to formalize their activities. The cartel members involved in kiosk partnerships are referred to as Kiosk Operators (KOs). They sell water to the consumers and pay the WSPs for the bulk water volumes supplied to the kiosks, as recorded by the water meters at these points.

In line with the partnership approach, the WSPs are responsible for sanctioning prices and overseeing operations at these water points. However, due to a limited ability to oversee and control on the part of the WSPs, the Kiosk Operators are "fully in charge" 10 of the activities at these water points. As most of these kiosks are put up by the operators, ${ }^{11}$ they feel entitled to determine the prices of the water they sell at their kiosks. Water is sold between 3 and $20 \mathrm{Ksh}$ for a 20-1 container instead of the 1.5-2 Ksh prescribed by the WSPs. In Kisumu, only 12 out of the 60 kiosks visited sold water at the recommended $2 \mathrm{Ksh}$ for a 20-1 container. At other kiosks, water was sold at 3 or $5 \mathrm{Ksh}$ for the same volume. Prices even go up further-to 10 or $20 \mathrm{Ksh}$-when operators deliver water to the doorstep of consumers. Also, in all six kiosks visited in Nakuru and the four visited in Kericho, water was sold between 3 and $20 \mathrm{Ksh}$, even when the formally regulated price of 1.5 and $2 \mathrm{Ksh}$ for 20 litres was displayed in bold letters on the kiosks (Fig. 2).

In making the partnership work, it seems that WSPs pay most attention to the financial aspects of their cooperation. Hence, as long as the kiosk operators pay the required bills, the WSPs do not seem overly concerned by the high water prices they charge. Where these high prices used to be seen as a problem when kiosk operators were still considered informal providers, the partnership with the WSPs has now turned them into a regulatory or enforcement problem. Because of the limited presence of the regulator (The Water Service Regulatory Board-WASREB) in the LIAs, consumers have no other option than to buy water at these high prices. The importance WSPs attach to the payment of bills is evident in the cutting off of supply to kiosks when operators fall behind on payments. This was observed in Kericho where 20 out of the 24 kiosks constructed by the WSP were disconnected due to the non-payment of bills by the kiosk operators. Also in Kisumu, an average of 15 water kiosks are disconnected at the end of each month for non-payment of bills ${ }^{12}$ and the utility has replaced post-paid water meters at water points with pre-paid meters, which requires payment from operators before selling water. Forty-five of such replacements have been carried out at different points in the city.

Riding on the back of these formal partnership arrangements, kiosk operators continue to control the supply of water in LIAs at the expense of the residents. Besides prices, the operators also decide when these kiosks are operational. They open and close access to these kiosks at their own convenience and not when residents need water.

\footnotetext{
${ }^{9}$ Here, the utility develops the primary connections and the private operators invest in the secondary pipes and the building of the water point.

${ }^{10}$ Interview, NGO staff Kisumu, 7 March 2017.

11 For instance, in Kisumu, only 10 out of the 340 kiosks were constructed by the utility.

12 These kiosks are reconnected when operators settle their bills.
}

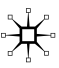



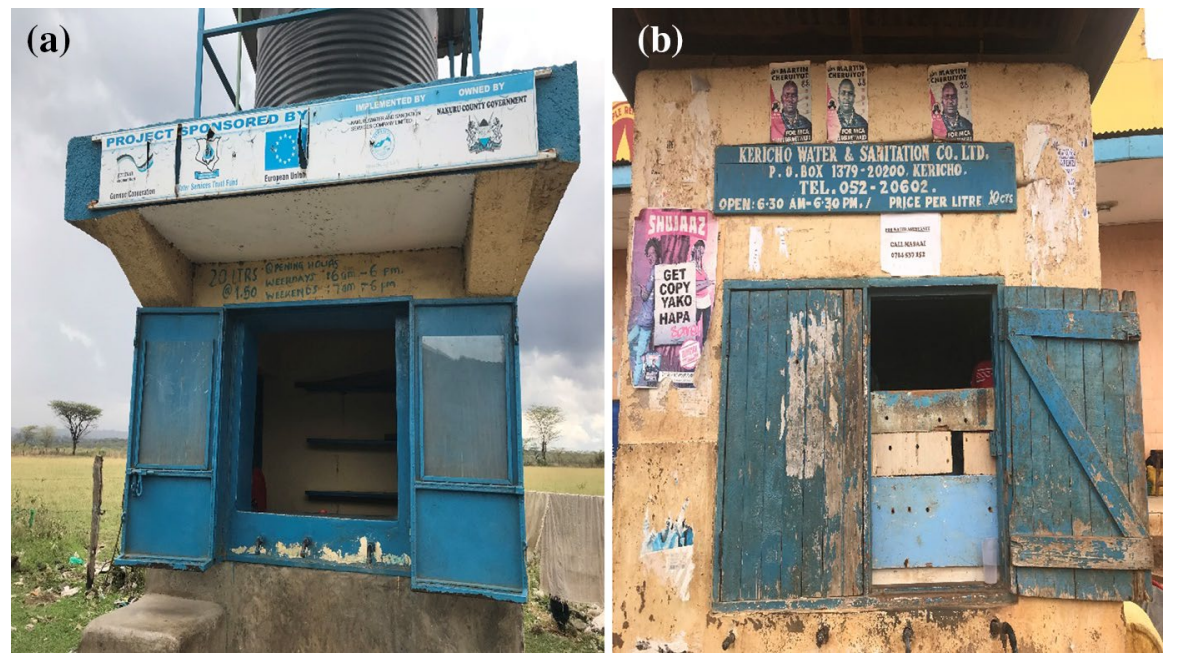

Fig. 2 Water kiosk in Nakuru (a) and Kericho (b) showing the price and opening hours; source (Authors' field note, February, 2016)

\section{Partnerships with Landlords}

Another partnership that WSPs adopt as an approach to formalization is with the landlords or landowners in the LIAs, through the construction of yard taps on compounds. From the perspective of the WSPs, this is beneficial in two ways. Firstly, it allows the bypassing of the legal challenge related to the lack of land tenure for connections in the LIAs. Even when land tenure is not a requirement for connections, as with the Delegated Management Model (DMM) in Kisumu (which we discuss in detail in the next section), landlords are often reluctant to allow tenants to have their own connections. Secondly, to develop piped networks in the LIAs, WSPs have to consult with the landlords and in some cases pay for laying pipes across their land. Those owners of lands who were already in the 'water business' resisted 'competition' from the formal utilities by refusing to give up their land or charging a very high price for it. The partnership with landowners therefore provides WSPs with an easy way to circumvent this problem. The yard taps, which are constructed either with pre-paid or post-paid water meters, are located on the plots owned by the landlords, who become responsible for delivering water to 10 or up to 50 households on their compounds

To the landlords who were already engaged in providing informal water services, the new partnerships afforded the opportunity to formalize what they were already doing on their own compounds. ${ }^{13}$ However, once this formality is accorded to them, all decisions on how water is supplied in these compounds also comes to lie with them. This was well articulated by a resident in Rhonda-Nakuru, "everything in this

13 Interview, staff KEWASCO, 27 March, 2017. 
house is decided by the landlord, the only thing you can make decisions about is what happens in your room". ${ }^{14}$ The control by the landlords starts with them deciding either to have the yard taps with post-paid meters (where they will be in charge of paying the bills to the WSP) or to have them with pre-paid meters (where residents pay for the water themselves). When they go for the post-paid meters, they decide either to sell water to residents or to add water charges to their rent.

Where water charges are added to the rent, landlords do it at their own discretion. In Nakuru, for instance, landlords who normally do not reside in these compounds add water charges of between 100 and $500 \mathrm{Ksh}$ to the rent that residents pay. This means that, irrespective of whether water flows (water supply in these areas is characterized by regular cut-offs, with water being only supplied twice per week for up to 2 or $3 \mathrm{~h}$ ), residents have to pay. The irregularity and unreliability of the supply forces them to also procure water from other sources-usually other paid water points. In such situations, monies paid as part of the rent are not refunded and residents cannot complain because the only alternative they have is to "find a different accommodation..., which is not a better solution, because the situation is the same everywhere". 15

In Kisumu and Kericho, landlords prefer to sell water from these yard taps to tenants. They do this to avoid the risk of incurring the extra costs from the over-use or mis-use of water by residents when charges are added to rent. Besides avoiding this risk, landlords also consider the re-sale of water as a means to make some extra money. Hence, allowing tenants to pay water charges with their rent or have parallel connections, as one landlord puts it, "will mean losing business......each landlord has to protect his or her territory.....houses here are not self-contained where one can have separate things". ${ }^{16}$ To increase their earnings from water sales, landlords may extend their water provisioning services to other residents (non-tenants) in their communities. Such yardtaps are kept locked when landlord or thier agents are not available to sell water to tenets (Fig. 3) ${ }^{17}$ Unlike with the kiosks where prices for water are sanctioned by the WSP, landlords in this partnership only have the responsibility of paying monthly water bills, so they control pricing. So important is the re-sale of water to landlords that they delegate this activity to a trusted tenant even when they do not live on the compound. With limited control from the WSPs, water, which is delivered to these yard taps at domestic rates, is sold at commercial rates (2 and $10 \mathrm{Ksh}$ ) by the landlords in this partnership.

\footnotetext{
14 Interview, resident Rhonda-Nakuru, 1 March, 2017.

15 Interview, resident Kaptemboi-Nakuru, 1 March 2017.

16 Interview, Landlord, Nyalenda-Kisumu, 17 March 2017.

17 It is worth mentioning that yard taps are also locked to prevent unauthorised access from nontenants.
} 

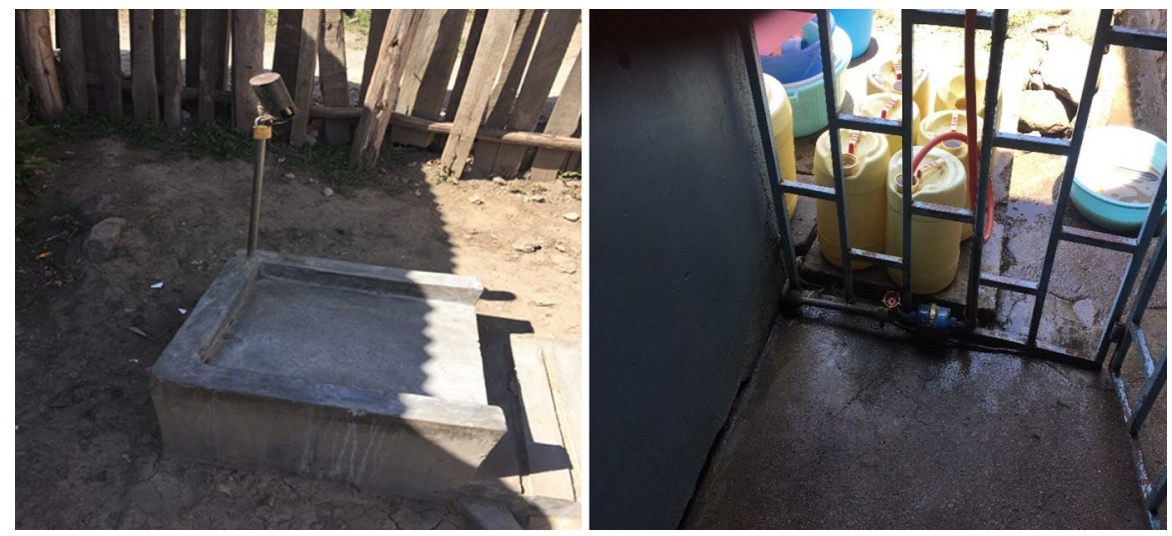

Fig. 3 Locked yard taps in LIAs; source (Authors' field note, March, 2017)

\section{From Cartels to Master Operators}

WSPs also form partnerships with the cartel members through organisational arrangements. One such arrangement in Kisumu is the DMM. In this model, the utility, Kisumu Water and Sewerage Company (KIWASCO) constructs the primary water pipe connections and installs bulk meters (referred to as master meters) at various points in the LIAs. The final chain of supply, which involves distributing water from the bulk meters to the consumers, is then contracted out to individuals or groups (CBOs), who are called Master Operators (MOs). In this partnership, the responsibilities of the MOs are twofold: to increase and improve connections in the LIAs through individual household connections, yard taps or water kiosks, ${ }^{18}$ and bill and collect revenues from connected connections. In total, 39 of such these DMMs are present in 6 out of the 22 LIAs in Kisumu city.

In forming these partnerships, KIWASCO is seeking to improve supplies and their performance in the LIAs by working together with and through the established informal providers. On paper, the MOs consist of groups of individuals who come together to form the CBOs that operate the DMM. In practice, however, MOs usually consist of "one individual; a previous cartel member who registers a CBO with people who may not even exist". ${ }^{19}$ Informal providers accept this arrangement, because, contrary to their former operations, registered MOs are accorded the formal status to connect and extend connections to consumers in the LIAs. Also in this model, land-tenure as a legal requirement for connections is eliminated. This gives residents easy access to water connections.

Besides cartel members gaining legal recognition, this arrangement affords the utility the opportunity to limit NRW rates in the LIAs. This is because MOs pay for every volume recorded by the master meter. ${ }^{20}$ They are expected to control or pay

\footnotetext{
18 Kiosks under this model are owned by individual or groups within the LIAs.

19 Interview, NGO staff, Kisumu, 7 March, 2017.

${ }^{20}$ Interview, Master Operator, Kisumu, 13 March 2017.
} 
(a)

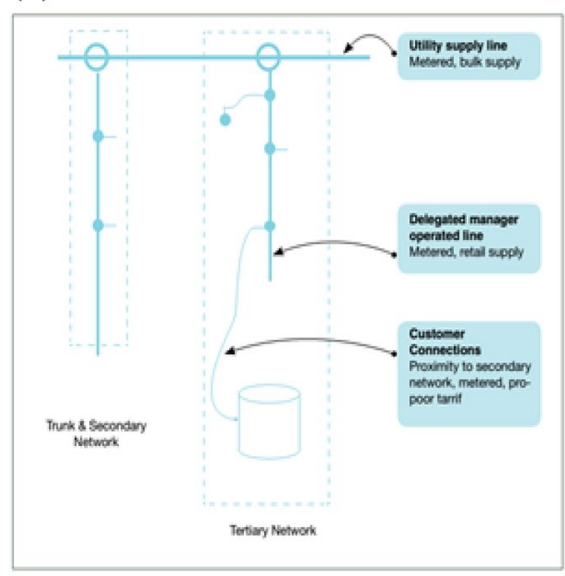

(b)

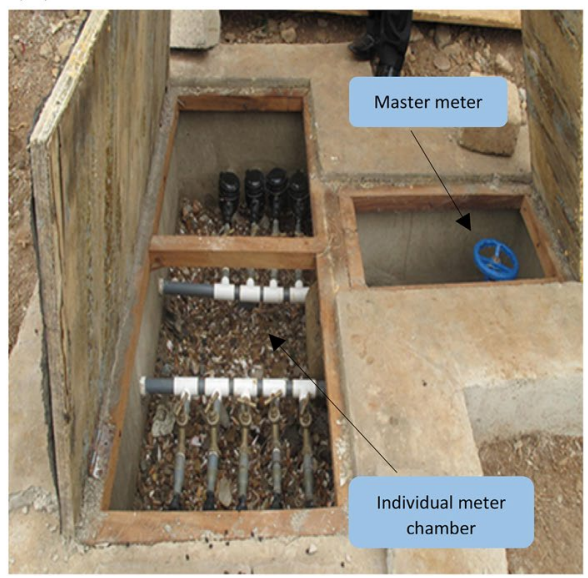

Fig. 4 a Shematic representation of the DMM; source (WSP 2009), and b pictorial representation of the DMM; source (Authors' field notes, February, 2016)

for whatever losses that occur within the secondary networks. In the event where the MOs default on payments to the water utility for bulk water, they lose their licence to operate the DMM. This was, for instance, the case of Nyawita (an LIA in Kisumu) where the utility had taken over the operation of all three DMMs due to non-payment of bills by the MOs. ${ }^{21}$ The relatively low NRW rate of less than $10 \%$ in LIAs served through DMM is an indication that the model has clear benefits for the water utility. To control the leakages, thefts and vandalism, and to ensure that bills to KIWASCO are paid promptly and in full, a number of different measures have been put in place in this model. One of these is the clustering and locking of household-level water meters in chambers (Fig. 4). The keys for these chambers are kept by the MOs. According to the official arrangements in the partnership, consumers can ask to check their meters whenever they want to. However, access to these meters is limited. Our interviews revealed that most residents have no idea what the meter records. They are simply expected to pay the bills they are presented with or risk disconnection. ${ }^{22}$ When they have genuine concerns about the bills, they have to first pay before they can complain or ask for anomalies to be fixed.

\section{Discussion: Serving the Poor or Satisfying Cartels}

Given the difficulties of formal utilities to provide water to LIAs, formalization of the informal sector appears to be a promising solution. Formalization involves a shift from perceiving the informal modes of service delivery as untoward, to

\footnotetext{
21 Such DMMs are re-advertised for new MOs to take over after the utility stabilizes the operations.

${ }^{22}$ Interview, resident Nyalenda-Kisumu, 17 March, 2017.
} 
pragmatically approaching them as 'arrangements that work' (Ahlers et al. 2014, p. 10). The above discussed partnership mechanisms show that such arrangements indeed seem to present a fit between the seemingly incompatible goals that formal WSPs have to meet: goals of universal access on the one hand and that of financial sustainability on the other. Through the partnerships, the cartels that used to control water distribution and service delivery in the LIAs have been absorbed into and made part of the formally recognized groups responsible for water provision. They become CBOs, or MOs operating the DMMs or KOs. In this way, LIAs have been effectively opened to the WSPs, leading to improvements in some aspects of access. The suspension of land titles as a requirement for extending connections in the DMM and the provision of kiosks and yard taps have made it easier for unserved households to get connected to the network and have regular access to water. The partnerships also lead to improvements in the network structure, and the use of high-quality materials may result in improved water quality. The WSPs also benefit directly from the process. The increase in the number of connections means an increase in their revenues while the reduction of illegal connections and vandalism of the network also translates into a significant lowering of NRW rates. For the WSPs and the regulators promoting such partnerships, they signify a means to extend supplies to 'difficult' areas without compromising commercial viability. For the water cartels, the partnerships offer a way to continue doing their business in a legal manner.

However, the quality of services provided to the LIA consumers raises questions which cannot be ignored. As the literature also shows, formalization in communities with substantial social inequalities may end up aggravating such inequities (Benjaminsen 2002; Jaglin 2016; Sjaastad and Cousins 2009). This is because formalization provides opportunities for the local elites to manipulate water provisioning to their benefit (Sjaastad and Cousins 2009). Indeed, the two lead partners in the newly formed partnerships, the utility and the now formal providers, primarily look out for themselves. The utility has conveniently shifted the risks associated with their services (mainly the risk of not recovering the costs of supplying water) in the LIAs to the MOs, KOs, CBOs and landlords. In the case of the DMM, for instance, the MOs have to protect the infrastructure because any damage or vandalism which results in losses of water means that they have to pay for water they did not sell. The now formal providers also have and feel the responsibility of protecting their investments while maintaining good working relationships with the utility by paying their bills. As evident from the discussion above, they secure their own earnings by shifting all losses to the consumers by charging high prices.

Besides curtailing the activities of the cartels, the partnerships also seek to involve the consumers in their water supply. However, in practice, decisions in the partnerships rest more with the WSPs and their new partners, leaving little or no room for the consumers to contribute. The sense of ownership which these models intended to develop thus remains limited to the members of CBOs, landlords, KOs and MOs. Even between the WSP and the formalized provider, the WSP has the upper hand. For the fear of losing their legality, these providers have to comply with the decisions the WSPs make even when they disagree. The importance the WSPs attach to the payment of bills 
leaves them with little room to control the activities of the providers in the LIAs. This leaves the formalized provider empowered to control or manipulate the system.

\section{Concluding Remarks}

With these findings, we question if the real effect of formalization is not the transfer of power from the "rowdy cartels" to organized ones, de facto resulting in a strengthening of their capacity to make profits on the backs of the LIA consumers. Instead of allowing residents to impact decisions, these partnerships seem to be making room for the 'local elites' to wield more influence and wealth, thereby maintaining or even reinforcing the very inequalities the interventions sought to eliminate in the first place. By institutionalizing such an association, with less attention given to the diverse interests of the various actors involved in the (in) formal service sector, inequalities in service provisioning become legitimized. In assuming that informality happens when existing rules and regulations are not binding enough, the intricacies of the informal sector are underrated. By so doing, the sector is viewed as one that can be shaped with ease to fit into the formal arrangements. However, as evident from these case studies, increasing or decreasing formality may not automatically translate into better or worse services for the poor, instead it may mean legalizing informality, leaving the urban poor worse off.

Acknowledgements This article is based on research conducted within the Performance Enhancement of Water utilities in Kenya through benchmarking, collective learning and innovative financing (PEWAK) project funded by the Netherlands Enterprise Agency.

\section{Compliance with Ethical Standards}

Conflict of interest On behalf of all authors, the corresponding author states that there is no conflict of interest.

Open Access This article is distributed under the terms of the Creative Commons Attribution 4.0 International License (http://creativecommons.org/licenses/by/4.0/), which permits unrestricted use, distribution, and reproduction in any medium, provided you give appropriate credit to the original author(s) and the source, provide a link to the Creative Commons license, and indicate if changes were made.

\section{References}

Angueletou-Marteau, A. 2008. Informal water suppliers meeting water needs in the peri-urban territories of Mumbai, an Indian perspective. Paper presented at the Global Changes and Water Resources: Confronting the Expanding and Diversifying Pressures: XIIIth World Water Congress.

Ahlers, R., F. Cleaver, M. Rusca, and K. Schwartz. 2014. Informal space in the urban waterscape: disaggregation and co-production of water services. Water Alternatives 7 (1): 1-14.

Ahlers, R., V. Perez Güida, M. Rusca, and K. Schwartz. 2013. Unleashing entrepreneurs or controlling unruly providers? The formalisation of small-scale water providers in Greater Maputo, Mozambique. The Journal of Development Studies 49 (4): 470-482. 
Bakker, K. 2003. Archipelagos and networks: Urbanization and water privatization in the South. The Geographical Journal 169 (4): 328-341.

Batley, R. (2006). Guest editor's preface. Symposium on non-state provision of basic services. Public Administration and Development 26 (3): 193-196.

Benjaminsen, T.A. 2002. Formalising land tenure in rural Africa. Forum for Development Studies 29 (2): 362-366. https://doi.org/10.1080/08039410.2002.9666212.

Berg, S.V., and S. Mugisha. 2010. Pro-poor water service strategies in developing countries: Promoting justice in uganda's urban project. Water Policy 12 (4): 589-601.

Boakye-Ansah A.S., Schwartz K., and Zwarteveen M. Forthcoming. Unravelling Pro-poor Water Services: What does it mean and why is it so popular?

Burt, Z., and I. Ray. (2014). Storage and non-payment: persistent informalities within the formal water supply of Hubli-Dharwad, India. Water Alternatives 7 (1): 106-120.

Castro, V., and A. Morel. 2008. Can delegated management help water utilities improve services to informal settlements? Waterlines 27 (4): 289-306.

Conan, H. 2003. Scope and scale of small scale independent private water providers in 8 Asian cities: preliminary findings. Manila: Asian Development Bank.

Conan, H., and M. Paniagua. 2003. The role of small scale private water providers in serving the poor. ADB working paper, Manila.

Cosgrove, W.J., and F.R. Rijsberman. 2000. World water vision: Making water everybody's business. London: Earthscan.

De Soto, H. 2000. The mystery of capital: Why capitalism triumphs in the West and fails everywhere else. New York: Basic Civitas Books.

Furlong, K. (2014). STS beyond the "modern infrastructure ideal": Extending theory by engaging with infrastructure challenges in the South. Technology in Society 38: 139-147.

Government of Kenya. 2010. The constitution of Kenya. Government of Kenya: Nairobi.

Heymans, C., Eales, K., and Franceys, R. 2014. The limits and possibilities of prepaid water in urban Africa: Lessons from the field. http://wwwwds.worldbank.org/external/default/WDSContentServe r/WDSP/IB/2014/08/26/000470435_20140826140705/Rendered/PDF/901590REPLACEM0Prepa id0Water0Africa.pdf. Accessed 14 May 2016.

Harris, C., and Janssens, J. 2004 Operational guidance for World Bank Group staff: public and private sector roles in water supply and sanitation services. (0199229309). http://documents.worldbank.org/curated/ en/556271468155727649/pdf/431020WP01NO0P1 vateSector1Roles1WSS.pdf. Accessed 10 July 2017.

Jaglin, S. 2008. Differentiating networked services in Cape Town: Echoes of splintering urbanism? Geoforum 39 (6): 1897-1906.

Jaglin, S. (2014). Regulating service delivery in Southern cities: rethinking urban heterogeneity. In The Routledge handbook on cities of the global south, 456-469. Routledge.

Jaglin, S. 2016. Is the network challenged by the pragmatic turn in African cities? Urban transition and hybrid delivery configurations. In Beyond the Networked City. Infrastructure reconfigurations and urban change in the North and South, ed. O. Coutard and J. Rutherford. Abingdon: Routledge.

Johnstone, N., Wood, L., and Hearne, R. 1999. The regulation of private sector participation in urban water supply and sanitation: Realising social and environmental objectives in developing countries: Environmental Economics Programme.

Kariuki, M., and J. Schwartz. 2005. Small-scale private service providers of water supply and electricity: A review of incidence, structure, pricing, and operating characteristics, vol. 3727. Washington, DC: World Bank Publications.

Misra, K. (2014). From formal-fnformal to emergent formalisation: fluidities in the production of urban watercapes. Water Alternatives 7 (1): 15-34.

Moretto, L. 2007. Urban governance and multilateral aid organizations: The case of informal water supply systems. The Review of International Organizations 2 (4): 345-370.

Njiru, C. 2004. Utility-small water enterprise partnerships: Serving informal urban settlements in Africa. Water Policy 6 (5): 443-452.

Njiru, C., I. Smout, and K. Sansom. 2001. Managing water services through service differentiation and pricing in an african city. Water and Environment Journal 15 (4): 277-281.

Ranganathan, M. 2014. 'Mafias' in the waterscape: Urban informality and everyday public authority in Bangalore. Water Alternatives 7 (1): 89-105.

Rusca, M., K. Schwartz, L. Hadzovic, and R. Ahlers. 2015. Adapting generic models through bricolage: Elite capture of water users associations in peri-urban lilongwe. European Journal of Development Research 27 (5): 777-792. 
Schaub-Jones, D. 2008. Harnessing entrepreneurship in the water sector: Expanding water services through independent network operators. Waterlines 27 (4): 270-288.

Schwartz, K., M. Tutusaus, and E. Savelli. 2017. Water for the Urban Poor: Balancing financial and social objectives through service differentiation for low-income areas in the Kenyan water services sector. Utilities Policy 48: 22-31.

Sima, L., and M. Elimelech. 2011. The informal small-scale water services in developing countries: The business of water for those without formal municipal connections. New Haven: Wiley.

Sjaastad, E., and B. Cousins. 2009. Formalisation of land rights in the South: An overview. Land Use Policy 26 (1): 1-9.

Solo, T.M. 1999. Small-scale entrepreneurs in the urban water and sanitation market. Environment and Urbanization 11 (1): 117-132.

Water Services Regulatory Board (WASREB). 2016. A performance reviewof Kenya's Water Services Sector 2014-2015. Issue No. 9/2016.

Winpenny, J. 2003. Financing water for all. Report of the world panel on financing water infrastructure. http://www.oecd.org/greengrowth/21556665.pdf. Accessed 8 July 2017.

World Bank. 2003. World development report 2004: Making services work for poor people. https://openk nowledge.worldbank.org/handle/10986/5986. Accessed 8 July 2017.

World Bank. 2009. Opportunities and challenges for small scale private service providers in electricity and water supply: Evidence from Bangladesh, Cambodia, Kenya and the Philippines. http://docum ents.worldbank.org/curated/en/346781468047737167/pdf/535040WP0SSPSP10Box345611B01PU BLIC1.pdf. Accessed 27 July 2017.

Water and Sanitation Program (WSP). 2005. Rogues no more? Water kiosk operators achieve credibility in Kibera. Water and sanitation program field note. http://www-wds.worldbank.org/external/defau 1t/WDSContentServer/WDSP/IB/2005/07/22/000011823_20050722175330/Rendered/PDF/33063 OPAPER0Rogues120No120More10Kibera.pdf. Accessed 18 March 2016.

Water and Sanitation Program (WSP). 2009. Improving water utility services through delegated management. Lessons from the utility and small-scale providers in Kisumu, Kenya. https://www.wsp.org/ sites/wsp.org/files/publications/Af-imp_through_delegated_mgmt.pdf. Accessed 22 April 2016.

Water Service Trust Fund (WSTF). 2010. Formalising water supply through partnerships. The MathareKosovo water model. http://www.waterfund.go.ke/toolkit/Downloads/2.\%20WSPs\%20Supplyin g\%20Informal\%20Settlements.pdf. Accessed 12 April 2017.

Publisher's Note Springer Nature remains neutral with regard to jurisdictional claims in published maps and institutional affiliations.

\section{Affiliations}

\section{Akosua Sarpong Boakye-Ansah ${ }^{1,2} \cdot$ Klaas Schwartz ${ }^{1,2}$. Margreet Zwarteveen ${ }^{1,2}$}

Akosua Sarpong Boakye-Ansah a.boakyeansah@un-ihe.org

1 Department of Integrated Water Systems and Governance, IHE-Delft Institute for Water Education, Westvest 7, 2611 AX Delft, The Netherlands

2 Amsterdam Institute for Social Science Research, University of Amsterdam, Nieuwe Achtergracht 166, 1018 WV Amsterdam, The Netherlands 